\title{
A Brief History of Open Educational Resources
}

\author{
T. J. Bliss ${ }^{\star}$ and M. Smith \\ Hewlett Foundation \\ *tjbliss@hewlett.org
}

\section{Editors' Commentary}

The Hewlett Foundation has been a key supporter of the open movement, donating over US170 million dollars over the past 15 years. In this chapter, authors T. J. Bliss and M. Smith-both of the Hewlett Foundation-ask whether this investment has been worthwhile. To answer this provocative question they trace the history of the open movement itself. They begin in the 1990s with fledging programs that formed the foundation for modern open education. From there, they cover the period they refer to as 'open's adolescence' from 2004 to 2010. Finally, they discuss recent trends in open, Hewlett Foundation funding priorities, and their hopes for the future of the movement.

\section{Introduction}

The Open Educational Resources (OER) movement is fifteen years old. This essay reviews OER's history, extraordinary growth, and place in education from the perspective of one current and one former employee of the William and Flora Hewlett Foundation. ${ }^{1,2}$ Since 2001, the Hewlett Foundation has provided just over US $\$ 170$ million to develop and extend the reach and effectiveness of OER. We tell the story of OER's development, provide examples and discuss uses of OER, and sketch its potential as a powerful tool for reducing

How to cite this book chapter:

Bliss, T J and Smith, M. 2017. A Brief History of Open Educational Resources. In:

Jhangiani, R S and Biswas-Diener, R. (eds.) Open: The Philosophy and Practices that are Revolutionizing Education and Science. Pp. 9-27. London: Ubiquity Press. DOI: https://doi.org/10.5334/bbc.b. License: CC-BY 4.0 
inequalities of educational opportunity and promoting innovative strategies to improve educational problems. We realize that our viewpoint shapes our discussion and our examples, thus we have deliberately referenced a large number of OER publications from a wide range of authors so the reader may explore materials that may have different perspectives.

\section{The Early History: 1994-2004}

Spurred by a 1994 National Science Foundation grant led by James Spohrer, in 1997, the California State University created MERLOT to identify and provide access to mostly free, online curriculum materials for higher education. ${ }^{3}$ Soon after, in 1998, David Wiley, an assistant professor at Utah State University, proposed a license for free and open content as an alternative to full copyright.

MERLOT, now with over 40,000 curated and rated items including over 700 separate psychology materials, provided the early means for college teachers to share intellectual content focused on teaching and learning and Wiley's insight made it easy to turn web-based or other educational materials open for others to use.

Simultaneously, Open Access (sharing research and other intellectual content) was growing from a tiny beginning in 1993 to the publication of PLOS in 2001, currently the largest of over 11,000 open journals including upwards of 700 focused on mathematics, and the Budapest Open Access Initiative ${ }^{4}$ in 2002, which helped establish open access as a world-wide approach to sharing research. These three extraordinary events set the stage for the rise of OER.

Ironically, however, also in the first two years of the new millennia, many American universities were attempting to sell their academic content, including elite institutions such as Yale, Columbia, and Stanford. Some institutions went the for-profit route while others chose to have their effort not-for-profit. ${ }^{5}$ With a few exceptions, all of the major institutions ended their effort within a few years.

But two major universities headed down a different path. At Rice University, engineering professor Richard Baraniuk, frustrated by the inability of the traditional publishing model to produce timely and relevant textbooks, was building Connexions, a web-based platform to facilitate the development and sharing of open source educational content by university professors all over the world. Connexions, which changed its name to OpenStax, now has over 20 free college level textbooks, including psychology, written by authors around the USA and has been projected to have saved students nearly US $\$ 40$ million.

And at the Massachusetts Institute of Technology (MIT), after a year-long wide-ranging debate, the faculty and administration committed themselves to freely share with the world the content of all of their courses. The idea for MIT OpenCourseWare (MIT OCW) grew out of discussions of the MIT Council on Education Technology in 1999, which was charged with determining how MIT should position itself in the distance learning ${ }^{6} / \mathrm{e}$-learning environment, 
provide a new model for the dissemination of knowledge and collaboration among scholars around the world, and contribute to the shared intellectual commons' in academia, which fosters collaboration across MIT and among other scholars. ${ }^{7}$ Its resolution was to open course materials so that anyone anywhere could benefit from MIT's knowledge. They audaciously proposed that course materials from all of their courses would be open to students and professors throughout the world. In the MIT OCW catalog today, there are over thirty psychology courses ranging from Introduction to Psychology to Neuroscience and Behavior and The Art and Science of Happiness.

Early in 2001, then-president Charles Vest visited the Mellon and Hewlett foundations requesting support to make as much content from MIT's roughly two thousand courses available freely online. Both foundations quickly provided multimillion dollar grants and the first fifty OpenCourseWare (OCW) courses, ably developed under the leadership of Executive Director Anne Margulies, were online by September $2002 .{ }^{8}$ On the west coast at Stanford in 2001, to support the legality of distributing and altering open materials, especially cultural works such as photos and music, Lawrence Lessig, Hal Abelson ${ }^{9}$, and Eric Eldred founded Creative Commons, an organization that develops and releases licenses for free and open materials across a wide range of areas. The work of Lessig et al. built on Wiley's earlier efforts. ${ }^{10}$

The Hewlett Foundation originally conceived of the MIT OCW grant as an important but one-time investment. As we considered alternative educational technology investments, however, MIT's powerful moral and ethical stance became more compelling, and by late 2002, we were focusing most of our technology work on providing open content and making it freely available. Thomas Jefferson captured the spirit of what we wanted to accomplish in a letter he wrote in 1813: ' $\mathrm{He}$ who receives an idea from me, receives instruction himself without lessening mine; as he who lights his taper at mine, receives light without darkening me."11

The Hewlett Board of Directors never challenged this direction and for almost 15 years has fully supported work on what became OER, even when some of our grants failed. When we first proposed the large MIT grant, Walter Hewlett, then chair of the board, expressed his understanding of MIT's instincts and shared with board members a story about how he had decided to make his music collection free after considering whether to sell it.

Early on, the Hewlett Foundation followed a simple strategy for stimulating open content. We provided grants to major universities beyond MIT, including Harvard, Carnegie-Mellon, Open University UK (OU UK), and Rice, where we gave Baraniuk a grant to help continue his work. We also funded the development of the OER Commons at the Institute for the Study of Knowledge Management in Education (ISKME). We took this direction in part to make a clear statement against the cliché, often cited by critics, that 'you get what you pay for.' Once certain content was made open to the public-MIT course materials, Harvard's creative library collections, and early versions of Carnegie-Mellon's adaptive cognitive tutor courses-that criticism was stifled. ${ }^{12}$ 
During the same period, we provided Creative Commons with a general support grant and funded both the Organization of Economic Cooperation and Development (OECD) and the United Nations Educational, Scientific and Cultural Organization (UNESCO) to stimulate interest in openly licensed educational materials in the developed and developing world. At a July 2002 UNESCO meeting of developing world nations in Paris, the name Open Educational Resources (OER) was coined and adopted for this new education innovation. While the thirst for openly licensed content was a clear outcome of this meeting, there was also a resounding uniform voice among the developing nations to be joint contributors to the open repository and not just consumers. ${ }^{13}$

\section{What Are OER?}

The Hewlett Foundation defines OER as 'teaching, learning, and research resources that reside in the public domain or have been released under an intellectual property license that permits their free use and re-purposing by others.' Creative Commons provides the licensing tools for permitting this free use and re-purposing; Hewlett considers the Creative Commons Attribution (CC BY) license to be the license of choice, allowing for maximal reuse and repurposing of copyrightable educational resources while still acknowledging the creative work of the developer. ${ }^{14}$

David Wiley elaborated on the idea of the permissions granted to an educational resource by an open license:

'The term "open content" describes any copyrightable work (traditionally excluding software, which is described by other terms like "open source") that is licensed in a manner that provides users with free and perpetual permission to engage in the $5 R$ activities:

1. Retain - the right to make, own, and control copies of the content (e.g., download, duplicate, store, and manage)

2. Reuse - the right to use the content in a wide range of ways (e.g., in a class, in a study group, on a website, in a video)

3. Revise - the right to adapt, adjust, modify, or alter the content itself (e.g., translate the content into another language)

4. Remix - the right to combine the original or revised content with other open content to create something new (e.g., incorporate the content into a mashup)

5. Redistribute - the right to share copies of the original content, your revisions, or your remixes with others (e.g., give a copy of the content to a friend). ${ }^{\prime 15}$

From Hewlett's perspective, a long-term goal is for an OER to be openly licensed (under a Creative Commons attribution license that includes the 5R activities), as well as technologically accessible and editable using generally available tools, 
and designed with diverse learners in mind. Deviation from any of these characteristics reduces the relative 'openness' of an educational resource. ${ }^{16}$

Not surprisingly however, much of the material now called OER (including some content funded by the Hewlett Foundation) do not meet all of these criteria. The Creative Commons licenses provide room for the author of the educational resource to restrict certain areas of use-for example, CC BY ND is a license that requires all users to acknowledge the author (BY) and not create derivatives (ND). Because it does not allow alteration of content, CC BY ND reduces much of the usefulness of the resource.

At its most fundamental level an OER has two powerful components: it is available for free to all and it is adaptable to serve the needs of the user. An ND clause on the license removes the second component-no longer may an OER be translated, altered, or mixed with other materials to improve its usefulness for new users. It may not be changed! MIT's OCW does not have ND on their license - faculty and students and others all over the world may adapt it for their own use.

Another somewhat controversial form of license, which is used by MIT OCW, is CC BY NC where the NC restricts commercial use. The NC condition seems on first glance to provide a simple protection against the transformation of open and free to closed and costly. In many instances this is a valid reaction. But one of the challenges for OER developers, including those that take developed OER and adapt it for a new population or purpose, is that it is very difficult to have a sustainable model for development and continuous improvement if there is no way to create a steady stream of funding. Foundations typically fund new innovations like OER for a while but then change their priorities to focus on something else. Even highly endowed universities do not favor activities that cannot support themselves or are not externally supported. The absence of a NC license allows everyone to have the original work for free and to adapt it however they wish and to market it for remuneration if they wish. For a special photograph or painting or a musical piece perhaps a NC license is particularly appropriate. For an open lecture or other piece of educational content, perhaps it is not.

Thus the big tent of licensed educational materials now generally called OER covers many configurations. While Hewlett's ultimate goal is to stimulate high-quality educational content without restrictions other than acknowledgement of the original content developer, we recognize that many developers have difficulties with losing control over their original work. Some may dislike allowing the original work to be modified or balk at offering their materials, which were intended to be free, without restricting users from making money from the new product. While such instincts are natural, the imposed restrictions have several major costs. They hamper people from tapping into their creative nature to directly build on existing materials and constrain access (e.g., by not allowing translations of the original material into other languages). They also limit the possibilities for business models that might sustain and improve the effectiveness of the content. The trade-offs are a struggle for everyone working in the green fields of OER, so while we prefer fully open resources, we understand and welcome the existing diversity. 
In the early years of OER before 2004, the Hewlett strategy towards how to leverage technology to support educational improvement changed from year to year. In 2004-2005 we adopted a more structured approach. ${ }^{17}$ At that time, Hewlett's overall goals focused on the promotion of free, useful educational materials for all. We saw this as a long-term effort and structured our work into three parts:

a. Supporting high-quality OER content providers in the developed and developing worlds. We deliberately supported many types of OER from different nations and parts of the world, such as OCW, full courses, teacher training, textbooks, lessons, and simulations. ${ }^{18}$ During this time period, OER Africa, a project of the South African Institute for Distance Education, was launched under the leadership of Catherine Ngugi in Narobi to support local OER communities across the African continent.

b. Building infrastructure and removing barriers to OER. While pipes and standards are important, infrastructure does not refer only to technical supports. We divided the infrastructure concept into three partstechnical, legal/social/cultural, and research-toward the goal of helping to design and motivate a self-sustaining environment that supported the widespread development and use of OER. ${ }^{19}$ More precisely, our intent was to advance opportunities for underserved people throughout the world and to stimulate new opportunities for learning and teaching by using the opportunity to adapt and combine OER materials to meet the specific needs of different teachers and students. The range of open materials including powerful simulations, partial lectures, and new assessment tools provided instructors all over the world with powerful tools that may have only been available in premier universities. On the technical side, our grants took into account massive changes in the delivery of information (e.g., increasing access to the internet and the rising importance of handheld devices) and the literature describing how openness can change behavior and expectations (e.g., the Long Tail, Wikipedia, MoveOn). We paid attention to the legal/social/cultural side through support of organizations, including Creative Commons, the internet Archive that regularly captures the entire web and sponsors creative collections of content; Connexions and other platforms to support OER; the Institute for the Study of Knowledge Management in Education (ISKME) to provide an open and easily accessible library of OER; ${ }^{20}$ and China Open Resources for Education (CORE) and Lucifer Chu's OOPS organizations to translate materials into Chinese. ${ }^{21}$ To improve and better understand the OER movement, we supported the Organisation for Economic C-operation and Development (OECD) and OU UK and their OER research efforts. ${ }^{22}$

c. Developing a world movement for open education. To fulfill this strategic goal, we amassed institutional supporters including UNESCO, OECD, 
Commonwealth of Learning (COL), and the Asia-Pacific Economic Cooperation ${ }^{23}$ created networks of producers and users of OER; and supported yearly meetings for people engaged in developing and using OER, including the annual Open Education Conference, the Open Education Global Conference, and Hewlett's own yearly OER meeting. We encouraged national governments to open their materials and research by working with leaders in countries and international agencies such as China, India, and the European Union. We also published articles in magazines like Change ${ }^{24}$ and Science ${ }^{25}$ and encouraged advocates for government support of OER in nations all around the world. ${ }^{26}$

Entering this phase, much of our attention focused on OER's usefulness at providing knowledge in its original form to those who otherwise might not have access. The implicit goal was to equalize access to disadvantaged and advantaged peoples of the world - in MIT's language to create 'a shared intellectual common. Our view captured this focus and extended it to K-12 (kindergarten through secondary) schooling and out-of-school learners as well as to higher education.

The open materials were quite diverse. For some free resources, such as the Open Learning Initiative at Carnegie Mellon, ${ }^{27}$ the content of the OER was designed to be practically impossible for a user to alter; thus, it was openly licensed but not technologically open. Other content, such as MIT OCW, could be used for educational purposes in any manner as PDF 'snapshots' of existing courses in whole or part. Over time, many MIT professors and others added video, simulations, pictures, and other materials to their websites, which could be used in the original form, altered, or adapted; thus, for example, professors around the world were able to draw on the MIT OCW when they design and teach their courses. The power and the inherent connection between open and adaptation gradually became evident to us during these early years and this knowledge began to influence our selection of grants.

An important benchmark occurred in late 2006. At the request of its board, the Hewlett Foundation supported an extensive review of the OER program conducted by three prominent education and technology experts, Daniel E Atkins, John Seely Brown, and Allen Hammond. ${ }^{28}$ The report, published in 2007, looked backward and forward. The authors dug deeply into the OER grants and their products and ultimately were enthusiastic about the progress the Foundation had made and recommended that the Hewlett Foundation continue to nurture global open educational resources, but to do so on a larger and more diverse scale and in the context of an even bolder goal-to shape a new culture of learning that is now possible in the digital world.

This report was presented to the Hewlett Board and gave the Foundation program the legitimacy and impetus to follow its initial strategic plan until 2011. It did so with a special focus on infrastructure, which provided a support for new OER to be created and released with Creative Commons' licenses 
all around the world with no financial assistance from Hewlett. Other organizations, including the Shuttleworth and Gates Foundations and the Open Society Foundation, had also entered the picture. The Gates Foundation was a supporter of the Khan Academy, perhaps the best known producer of OER other than MIT. Established in 2006 and seriously underway by 2009, Khan's materials have helped hundreds of millions of people learn online, have been translated into 65 languages, and are used in schools and community colleges around the world for remedial and blended learning. ${ }^{29}$ Hewlett has not provided support for Khan Academy.

During this period, the world movement in support of OER flourished. In particular, two significant international meetings affirmed OER: the Shuttleworth Foundation supported a meeting in South Africa in 2008 and UNESCO hosted an OER World Congress in Paris in 2012. Each meeting involved representatives from dozens of nations who voiced their commitment to OER. Importantly from our perspective, neither of these meetings was funded or led by the Hewlett Foundation. ${ }^{30}$

Open Access (OA) had also grown rapidly along with OER. The OA initiative responded to the pace of science and the need to ease the path of new knowledge by openly distributing research studies and data. The Scholarly Publishing and Academic Resources Coalition (SPARC), a primary advocate for OA in the United States led by Executive Director Heather Joseph for over a decade, has been a strong partner in the open theater more generally. Specifically, SPARC recently hired a director of Open Education to further its efforts in the OER space. Today, such advocates of OER are found in dozens of nations. ${ }^{31}$

Finally, the early years of this decade saw the rise of Massive Open Online Courses (MOOCs) produced by some of the most well-known universities in the United States and around the world. While free, online courses have existed for years-like the Virtual University of Pakistan, which digitizes and freely disseminates all its classes on YouTube and through other means-MOOCs have captured the imagination of mainstream media. Although 'open' is in the name, only a relatively few MOOCs are free and only a handful carry a Creative Commons license that would allow user institutions or individuals to alter and adapt the content. ${ }^{32}$ But even though most MOOCs are not OER, their rise has generated interest in valuable content that has hitherto been impossible for almost all of the world's population to access. In this regard, the MOOCs arguably have contributed positively to the open movement and fall within Jefferson's vision of sharing ideas - certainly the free MOOCs would meet his standard. ${ }^{33}$

\section{A Change in Strategy: 2011-2015}

With the release of a new strategic plan in late 2010, Hewlett sought to deepen the movement by 'going mainstream' and focusing more attention on improving educational practice in the United States. ${ }^{34}$ Hewlett continued its support of key 
OER infrastructure efforts but also provided grants for creating more polished, market-ready primary resource products, such as full end-to-end K-12 curricula and complete textbooks aligned to higher education courses with problem sets and teacher supports. In the United States, as part of its new strategy, Hewlett linked its OER efforts with its priority supporting the implementation of the Common Core State Standards by helping EngageNY, which provides openly licensed Common Core-aligned curricula in K-12 school mathematics and English language arts. To date, the EngageNY curricula have been downloaded more than 20 million times in schools throughout the country and the world. ${ }^{35}$

Hewlett has also promoted the use of open textbooks at the $\mathrm{K}-12$ and college levels to great success. Many of the open textbooks produced by $\mathrm{CK}-12^{36}$ and K-12 OER Collaborative are used in K-12 schools around the world. Hewlett, Gates, and the California government also support the integration of OER into the existing public higher education system through an organization called the California Open Educational Resources Council, which promotes the use of open textbooks and other materials. ${ }^{37}$ At the collegiate level, the use of open textbooks produced by such organizations as OpenStax College, BCcampus, and Lumen Learning has become quite popular, particularly as it helps to reduce students' financial burden. ${ }^{38}$

The mainstream strategy also focused on involving federal governments in the OER movement. Creative Commons and SPARC have led the effort to encourage the government to support open research and the development of open educational products. In fall 2015 the US Department of Education and the White House Office of Science and Technology Policy announced new open policies supportive of the development of OER. ${ }^{39}$ At the end of that year, the US Department of Labor announced a regulation requiring all intellectual property developed under a competitive Labor Department grant be released with a CC BY license. ${ }^{40}$

The United States is not alone-governmental adoption of OER is moving quickly throughout the developed world. In a book released in 2015, the OECD reports: 'In August and September 2014, governments were asked to respond to a CERI/OECD questionnaire on how they support and facilitate the development and use of OER in all education sectors. The survey collected the responses of 33 countries: 29 OECD member countries and 4 accession and key partner countries (Brazil, China, Indonesia and Latvia). The results indicate a clear policy support for OER, with 25 countries reporting having a government policy to support OER production and use. ${ }^{41}$

\section{Has It Been Worth US\$170 Million?}

Hewlett's commitment to OER is not over, but it has been 15 years since we first funded MIT OCW - a substantial amount of time-so we should consider whether our investment in OER has been worth it. 
This is an existential question-the answer depends on who we are asking and on what an imagined alternative might have produced. One consideration is that just over US\$170 million already spent developing OER has led to positive outcomes and will also produce future benefits. Another consideration has to do with values and goals of the Foundation, which emphasize the 'well-being of mankind' and the support of practical innovation. A third consideration is that although this effort was heralded by some as a 'magic bullet' that would easily solve complex problems in education, this proved not to be the case.

Hewlett has never treated its support for OER as a short-term trial, one to be dropped as priorities changed. Rather, throughout the years, Hewlett has remained committed to its original goals of making OER a powerful tool to improve the equality and quality of educational opportunity around the world. Since 2003 the Foundation has treated its grants in OER as providing support for a social movement that in time should be self-sustainable. ${ }^{42}$ The steady increase of nations adopting legislation or regulation that support and sometimes require the use of open licenses is one measure of positive growth of self-sustainability. While the OER movement has not fully achieved scale, it is well on its way.

The extent of coverage for higher education from MIT OCW and its many translations into different languages is enormous. More than 100 million unique visitors, including scholars, teachers, and students, have explored content on the MIT site (and millions more who speak and read in languages other than English have visited the sites of the 250 higher education institutions from all over the world in the Open Education Consortium). Previously, only students who could afford four years at MIT or another elite institution would have been able to access the OCW content, but now professors, students, and people all over the world can draw on these resources for knowledge. Thousands of open textbooks and hundreds of full open courses are now available for the most highly enrolled US college courses and are being translated into many languages, ${ }^{43}$ helping more students afford college. ${ }^{44} \mathrm{PhET}$ science simulations have been downloaded over 275 million times. Teacher Education in Sub-Sahara Africa (TESSA), COL, and TESS-India support high-quality professional development for teachers in a half dozen African nations and seven states in India, together influencing teachers of hundreds of thousands of students. ${ }^{45}$

At the K-12 level, Khan Academy materials have had hundreds of millions of users. An important byproduct is the work of the Foundation for Learning Equality (FLE); FLE has developed a method for delivering Khan and other educational materials in settings where there is no connectivity and no electrical power. ${ }^{46}$ FLE has brought educational materials to an estimated 2 million-plus users through its work with large non-governmental organisations (NGOs) in refugee camps, US prisons, and other resource-limited settings. Full K-12 open curricula reaching millions of students are available in English, as are hundreds of textbooks and online courses. Open textbooks are also available in dozens of countries. ${ }^{47}$ 
There are still barriers and problems in the OER world even though many nations have endorsed the use of OER. Surveys indicate that only a small percentage of professors and teachers know very much about OER even if they use open materials. We expect this number to improve over time, however, as teachers and professors adapt and draw on the openly licensed materials. Another potential barrier comes from the publishing industry because, as a practice, the use of OER threatens their business model. Still, we expect that the industry's modes of delivery and possible sources of income will adapt to OER. This trend is pushed by models for curricula changing more toward using the internet, examples of MOOCs and OCW becoming more evident and teachers developing a greater understanding of ways to adapt materials to their students. It is clear that the age of the bound textbook that stays unchanged for six years will soon be over.

These and other problems are real challenges but they now seem solvable. This optimism and the strong increase in the raw numbers for the creation and use of OER as well as the positive activity at the government level around the world indicate a healthy, useful and vibrant OER movement.

\section{The Next Stage: OER Helping to Solve Problems: 2016 and Beyond}

We believe that the OER movement now has staying power without major support from the Hewlett Foundation. One of many signs of independence of the movement is that a group of OER activists and leaders recently published a living OER strategy document that may be adapted and modified and is designed to address 'strategic questions about how we, as the global OER movement, can reach our collective goals. ${ }^{38}$

In late 2015 the Foundation released a refreshed strategic approach for its OER portfolio, describing Hewlett's three goals: strengthening infrastructure, using OER to help solve social and educational problems, and improving educational materials.

The focus on infrastructure will include supporting institutions such as Creative Commons and ISKME that have been mainstays of the OER movement and on increasing the quality and quantity of research projects and descriptions of OERs use and effectiveness. The OU UK, OECD, and UNESCO already provide a steady stream of useful description and research on OER, while the International Development Research Centre in Canada supports local researchers in the developing world who study the use and effectiveness of OER interventions. ${ }^{49}$ It is important to note that work carried out by local researchers might be especially useful in the developing world because the findings would have regional credibility. Such infrastructure involvement also has the side benefit of supporting Open Access, Open Culture, and Open Government.

For the second goal Hewlett will fund tailored, innovative interventions and strategies that use OER as a tool to help solve social and educational problems. 
On top of the list are traditional problems of inequity and opportunity. Since these problems vary, the contribution of OER also may vary. OER cannot address or ameliorate all of the inequalities in the access to knowledge and education but with careful and sustained attention, some may be lessened.

At the heart of the concept of OER is freedom: freedom of access to content, freedom from cost, and freedom to use in any way. Large classes of people in the United States and across the globe do not receive an adequate education due to a lack of finances or other resources. By providing free access to powerful education content, OER can help underserved populations such as children and youth in prison or foster care, Native Americans in government schools, and students from low-income families or who must learn English as a second language. When it comes to tertiary education, which has a high cost particularly in the United States, the financial barrier may be partially offset by high-quality open textbooks and online courses. Though Hewlett has already supported OER work in some of these settings, much more can be done.

Even more egregious problems exist overseas, particularly in the developing world. The Foundation has been allocating resources into this area, for instance, supporting FLE in its work with large intergovernmental organisations (IGOs) to provide education in areas that lack connectivity and sometimes even electrical power. These settings, which include refugee camps and thousands of tiny, low-priced, low-cost private schools in East Africa, Pakistan, and India, are in dire need of open materials and effective delivery systems. ${ }^{50}$ Another problem is teacher training, which is often widely neglected in many parts of the developing world; TESSA in Africa and TESS-India provide existing OER models that also could be used in many other settings. And the OER Commons, developed by ISKME founder and CEO Lisa Petrides, has expanded its focus to extend to educators across the globe.

Such successes suggest other strategies that could work in locations in the developing and developed world. Open MOOCs and video could be used for pre-service training for teachers. Many institutions, especially in low-income countries, lack laboratories for science experiments and medical diagnostic opportunities. This deficiency might be partially offset by providing these institutions access to open, high-quality virtual laboratories, diagnostic rooms, and operating rooms. Another more ambitious example supported by Hewlett might be the Peer to Peer University (P2PU), an open, free institution that provides free courses and largely relies on the power of sharing and collaboration among its students. Now may be the time to consider whether this innovation is working and, if it is working well, to expand or replicate it to meet global needs. All of these efforts exemplify the kind of OER-focused work that will help balance the equality scales.

Hewlett's third goal in the OER arena is to improve the quality and usefulness of educational materials. As free platforms making it easier to adapt and mix content become more usable, teachers and other educators can piece together OER from multiple sources to create curriculum geared toward the needs of 
their specific classrooms and schools. Professional networks of teachers and others who openly share extend this power of the freedom to collaborate and build. The growing capacity and ease of translating materials from one language into others further increases the scope of materials available at the local level. Such efforts all support the ability of OER to bring about continuous improvement and innovation.

A related, potentially powerful and innovative approach to improving content quality was sketched out in the 2007 independent review of Hewlett's OER program. Thinking on a big scale, the two authors argued: 'We believe that the Hewlett Foundation can play a leadership role in weaving the threads of an expanded OER movement; the e-science movement; the e-humanities movement; new forms of participation around Web 2.0; social software; virtualization; and multimode, multimedia documents into a transformative open participatory learning infrastructure - the platform for a culture of learning.'

Atkins et al. (2007) sketched the dimensions of their vision of an infrastructure of learning built around OER. ${ }^{51}$ Perhaps this is only an idealized vision but in 2016 it may well be a vision worth exploring. It fits the quality, usefulness, and big-problems criteria of the OER agenda. ${ }^{52}$

\section{A Final Word}

The world of OER is vibrant, challenging, and filled with tremendous possibilities. To quote the new vision document: 'The Hewlett Foundation is excited to continue supporting OER at a time that the field is building on its successes and transitions to solving some of the most pressing problems that teachers and students face throughout the world. With this new problem-based approach, the Foundation looks forward to many more students benefitting from the promise of OER.'

\section{Notes}

${ }^{1}$ Other Hewlett employees directly responsible for elements of the OER portfolio referenced throughout this paper include Catherine M. Casserly, program officer/OER initiative director (2001-2009); Kathy N. Grant, associate program officer/program officer (2009-2014); Vic Vuchic, program officer (2007-2014); and, Dana Schmidt, OER program officer (2014-2016).

2 We thank Catherine Casserly and Victor Vuchic for their comments on earlier versions of this text. We also thank Vijay Kumar of MIT and Cable Green of Creative Commons, both important OER advocates, for their comments.

3 The grant was 'Authoring Tools and an Educational Object Economy' (EOE) and was led by James Spohrer and hosted by Apple Computer and other industry, university, and government collaborators. The EOE developed and 
distributed tools to enable the formation of communities engaged in building shared knowledge bases of learning materials. MERLOT, the acronym for Multimedia Educational Resources for Learning and Online Teaching, is a robust site with links to over 40,000 teaching and learning resources. MERLOT maintains a link for each resource as well as metadata, which contain information about the cost (if any) and the use permissions for each of the materials. Simultaneous a federal working group led by Kurt Winters in the Department of Education in response to a memo from President Bill Clinton conceived the FREE initiative in 1997 which collected and made available the most highly rated free government educational content, see http://clinton2.nara.gov/WH/New/NetDay/memorandum.html. The FREE site was closed in June 2015.

${ }^{4}$ For more information, please see http://www.soros.org/openaccess/read. shtml.

5 'Oxford, Yale and Stanford closed their joint not-for-profit online venture, AllLearn (Alliance for Lifelong Learning) citing insufficient enrollments and funding as the primary reasons. AllLearn was established in 2001 at the peak of the dot-com boom to offer online non-credit courses in general interest subject areas. The initial audience was the alumni of the three institutions, but as of the autumn semester 2002, provision was opened to the general public. After almost five years in operation, the three universities have released a joint statement concluding that 'the cost of offering top-quality enrichment courses at affordable prices was not sustainable over time.' Following a series of collapsed e-university ventures from US universities (e.g., NYU Online, Fathom, Virtual Temple, and University of Maryland University College Online), AllLearn is another major product of the dot-com boom to fold.' See https://ox-d.promediagrp.com/w/1.0/afr?mi=ec00476ba355-4ab0-fa02-ba6a24422bb9\&ma $=1454266450 \& \mathrm{mr}=1455476050 \& \mathrm{mn}=$ $1 \& \mathrm{mc}=1 \& \mathrm{cc}=1$ \&auid $=33998 \& \mathrm{cb}=0.36133100 .1454266136$.

${ }^{6}$ For more information, please see https://en.wikipedia.org/wiki/Distance_ learning.

${ }^{7}$ See https://en.wikipedia.org/wiki/MIT_OpenCourseWare.

${ }^{8}$ See https://cnx.org and http://openstax.org for the Connexions project (now called OpenStax) at Rice, and see www.creativecommons.org for Creative Commons. See http://ocw.mit.edu/index.htm for MIT OCW.

9 For more information, please see https://en.wikipedia.org/wiki/ Hal_Abelson.

${ }^{10}$ For more about the Creative Commons, see http://creativecommons.org.

${ }^{11}$ Jefferson's letter went on: 'That ideas should freely spread from one to another over the globe, for the moral and mutual instruction of man, and improvement of his condition, seems to have been peculiarly and benevolently designed by nature, when she made them, like fire, expansible over all space, without lessening their density in any point, and like the air in which we breathe, move, and have our physical being, incapable of confinement 
or exclusive appropriation. Inventions then cannot, in nature, be a subject of property' See http://press-pubs.uchicago.edu/founders/documents/a1_ 8_8s12.html for the full text.

12 For the Harvard collections, see http://ocp.hul.harvard.edu; for the CarnegieMellon Online Course Initiative, see http://oli.cmu.edu; and for the Connexion project at Rice, see cnx.org.

13 See the UNESCO meeting report: http://www.hewlett.org/uploads/files/ OpenCourseWareandDevelopingCountries.pdf. See also OECD at http:// www.oecd.org/edu/ceri/givingknowledgeforfreetheemergenceofopen educationalresources.htm and UNESCO workon OER athttp://www.unesco. org/new/en/communication-and-information/access-to-knowledge/openeducational-resources/.

${ }^{14}$ While the CC BY license is often thought of as the least restrictive Creative Commons license, it requires acknowledgement of the originator. When there are multiple serial redesigns of the same content, even the CC BY license becomes awkward; thus there is an even less restrictive license (CC0), which eliminates the acknowledgement requirement.

15 Retrieved from http://opencontent.org/definition/ on December 4, 2015.

${ }^{16}$ Other aspects of openness beyond legality are often considered with OER, including technological openness and accessibility. Technological openness refers to the freedom available to an end user to engage in the 5R activities. For example, content that is legally open but hidden behind a paywall or distributed in a format that restricts repurposing is not within the spirit of open content. Similarly, content that is openly licensed and technologically open but not designed with general accessibility in mind is not fully open content. Jutta Treviranus, the director of the Inclusive Design Research Centre at the Ontario College of Art and Design University, explains, 'Correctly designed digital resources can transform to the unique specifications of each learner, presenting the visual layout, presentation modes (e.g., audio, visual, tactile), and method of control that suits the individual learner.' Treviranus argues further that OER should be designed for diverse learners, not just for the typical student. Personal communication to T. J. Bliss, July 2015.

17 The metrics for OER growth are difficult. The number of hits for the term Open Educational Resources was zero in a Google search in 2002, in the tens of thousands in 2006-2007 when we were watching it, and now is in the hundreds of thousands. It is even more difficult to measure the term OER, which now has more than 20 million hits with more than 90 percent of the first ten pages referring to Open Educational Resources. Until the fall of 2005, almost the entire first page of a Google search for Open Educational Resources directed to sites that Hewlett funded-by mid-2006, fewer than half of the citations on the first page referred to Hewlett-supported projects. See http://www.hewlett.org/uploads/files/OER_overview.pdf for an interesting report of the work up through 2005. 
${ }^{18}$ For information about OER work from 2004-2010 at various institutions, see: http://www.open.edu/openlearn/ for the Open University of the United Kingdom (OU UK); https://www.col.org/news/speeches-presentations/ open-education-resources-oer-what-why-how for the Commonwealth of Learning (COL) work on OER; http://www.oeconsortium.org for the Open Education Consortium; http://www.oecd.org/edu/ceri/38149140. pdf for the Open University of the Netherlands; https://phet.colorado.edu for PhET's interactive science simulations; http://www.tessafrica.net for TESSA; http://iite.unesco.org/pics../publications/en/files/3214700.pdf and https://en.wikipedia.org/wiki/China_Open_Resources_for_Education for CORE; and http://www.oerafrica.org for OER Africa.

19 Without being aware of it, our approach was similar to Edwards et al's [2007] theory of infrastructure, which requires attention to legal, technical, cultural, social, political, and financial components. See Paul N. Edwards, Steven I. Jackson, Geoffrey C. Bowker, and Cory P. Knobel, 'Understanding Infrastructure: Dynamics, Tensions, and Design.' January 2007. http:// deepblue.lib.umich.edu/handle/2027.42/49353. See also Marshall S. Smith and Phoenix Wang, 'The Infrastructure of Open Educational Resources.' Educational Technology, v. 47, n. 6, pp. 10-14, Nov.-Dec. 2007.

${ }^{20}$ ISKME is the Institute for the Study of Knowledge Management in Education. See http://www.iskme.org.

${ }^{21}$ OOPS is a volunteer-based localization project with the goal of translating open knowledge into Chinese. More than 20,000 volunteers are estimated to have joined OOPS (Opensource Opencourseware Prototype System), which translates MIT and other OCW into Mandarin. CORE is China Open Resources in Education. For a longer discussion of OER and China, see http://iite.unesco.org/pics../publications/en/files/3214700.pdf and for more information about translations of MIT OCW and other OCW, see http://ocw.mit.edu/courses/translated-courses/.

${ }^{22}$ See, for example, http://www.oecd.org/edu/ceri/38654317.pdf and http:// www.open.ac.uk/score/events/learning-oer-research-projects. For a more recent discussion of research, see http://www.hewlett.org/research-openoer-research-hub-review-futures-research-oer and http://www.hewlett. org/sites/default/files/OER\%20Research\%20paper\%20December\%20 15\%202013\%20Marshall\%20Smith_1.pdf.

${ }^{23}$ See, for example, https://www.col.org/, http://www.nba.co.za/asia-pacificeconomic-cooperation-apec-oer and http://www.apec.org.

${ }^{24}$ See Marshall S. Smith and Catherine M. Casserly, 'The Promise of Open Educational Resources.' Change: The Magazine of Higher Learning, v. 38, n. 5 pp. 8-17, Sept.-Oct. 2006.

25 See Marshall S. Smith, 'Opening Education.' Science v. 323, n. 89, pp. 89-93, Jan. 2, 2009.

${ }^{26}$ For an example of advocacy, Hewlett funding helped support Vijay Kumar's work with India's National Knowledge Commission, leading to 
strategic recommendations to use OER to extend access to quality educational opportunity in India. See http://eprints.rclis.org/7462/1/National_ Knowledge_Commission_Overview.pdf and http://www.sampitroda.com/ knowledge-commission/. Also see http://iite.unesco.org/pics../publications/ en/files/3214700.pdf for information about the adoption of OER in various nations.

27 See http://oli.cmu.edu.

${ }^{28}$ See A Review of the Open Educational Resources (OER) Movement: Achievement, Challenges, and New Opportunities (2007) at http://www.hewlett. org/uploads/files/ReviewoftheOERMovement.pdf, authored by Daniel E. Atkins, professor of Information, Computer Science, and Electrical Engineering at the University of Michigan and former director of the Office of Cyberinfrastructure, US National Science Foundation; John Seely Brown, former chief scientist of Xerox and director of its Palo Alto Research Center; and Allen Hammond, former vice president for Innovation and Special Projects at World Resources Institute.

29 See khanacademy.org.

${ }^{30}$ For a discussion of government policies and OER, see http://www.slide share.net/oeconsortium/impact-of-international-organizations-ongovernmental-oer-policies-48013353. For more information on the meetings, see https://en.wikipedia.org/wiki/Cape_Town_Open_Education_Declaration and the resolution from the 2012 UNESCO World OER Congress: http:// ru.iite.unesco.org/files/news/639202/Paris\%20OER\%20Declaration_ 01.pdf.

${ }^{31}$ See http://www.sparc.arl.org and https://en.wikipedia.org/wiki/Open_access.

32 As always, there are a few exceptions. For example, the online learning destination edX makes many of its MOOCs free but not alterable while the edX platform itself has open-source code, which is free to use. In 2015 Creative Commons worked with edX to make it simple to add a CC license to edX MOOCs.

${ }^{33}$ For more about MOOCs, see https://en.wikipedia.org/wiki/Massive_open_ online_course.

${ }^{34}$ See Hewlett Education Program Plan Fall 2010: http://www.hewlett.org/ uploads/documents/Education_Strategic_Plan_2010.pdf. To support the change, the Foundation noted, 'After eight years of field building with the Hewlett Foundation as its primary supporter, OER is beginning to shift from a nascent movement to a respected force in education. The movement was featured in both the New York Times and Wired magazine in 2010. At the same time, other foundations dramatically increased OER funding, and federal grant programs began to include OER as a priority in their grant application guidelines, signaling greater acceptance of the field.'

35 See http://www.edweek.org/ew/articles/2015/06/10/ny-open-educationeffort-draws-users-nationwide.html.

${ }^{36}$ See http://www.ck12.org/student/. 
37 See http://icas-ca.org/coerc.

${ }^{38}$ See http://www.ck12.org/student/, http://k12oercollaborative.org/ https:// openstaxcollege.org/, http://bccampus.ca/, and http://lumenlearning.com.

39 See http://www.ed.gov/news/press-releases/us-department-educationlaunches-campaign-encourage-schools-goopen-educational-resources.

${ }^{40}$ See http://ies.ed.gov/ncee/wwc/quickreview.aspx?sid=245.

${ }^{41}$ See Dominic Orr, Michele Rimini, and Dirk van Damme, Open Educational Resources: A Catalyst for Innovation. Educational Research and Innovation, OECD Publishing. Paris, 2015, p. 20. See http://www.oecd-ilibrary.org/ docserver/download/9615061e.pdf? expires=1451782268\&id=id\&accname =guest\&checksum=A8C62EF8A123FB6D46F068B779098A8E.

${ }^{42}$ In 2006 Gary Matkin from the University of California at Irvine wrote about OER as a movement. See 'The Open Educational Resources Movement: Current Status and Prospects' at http://unex.uci.edu/pdfs/dean/matkin_ apru_paper.pdf.

${ }^{43}$ For examples of open higher education textbooks in psychology, see the following web sites as of Nov. 30, 2015. This is only a sampling of the material on the web: https://open.umn.edu/opentextbooks/SearchResults.aspx? subjectAreaId=7, http://nobaproject.com, http://library.calstate.edu/text book/?isbn=9780073532073\&button=Search\&type=books, http://cnx.org and http://ocw.uci.edu.

${ }^{44}$ For example, see references to the importance to students of free textbooks in two major mass media outlets. See http://www.usnews.com/ education/best-colleges/paying-for-college/articles/2013/08/14/4-waysto-get-free-college-textbooks and http://www.cnn.com/2014/04/18/living/ open-textbooks-online-education-resources/. For an example of the use of textbooks in other parts of the world, see https://www.col.org/programmes/ technology-enabled-learning/eastern-caribbean-open-textbook-forumsupports-oer-strategies.

45 See http://www.tessafrica.net, https://www.col.org/programmes/teachereducation, and http://www.tess-india.edu.in.

${ }^{46}$ See Foundation for Learning Equality at https://learningequality.org.

47 For an interesting review of the use of OER in the British Commonwealth, see https://www.col.org/news/speeches-presentations/open-educationresources-oer-what-why-how. For examples of use of open textbooks in the United States, see http://www.ck12.org/; http://www.uen.org/oer/. For an example of the use of open textbooks and professional development in Africa, see http://www.siyavula.com/.

48 oerstrategy.org, 'Foundations for OER Strategy Development.' Version 1.0. Nov. 18, 2015. Drafting Committee: Nicole Allen, Delia Browne, Mary Lou Forward, Cable Green, and Alex Tarkowski. See http://www.oerstrategy. org/home/read-the-doc/.

49 See http://www.idrc.ca/en/themes/information_and_communication/pages/ projectdetails.aspx? projectnumber $=107311$. 
${ }^{50}$ Global Business Coalition for Education (2016) Exploring the Potential of Technology to Deliver Education \& Skills to Syrian Refugee Youth. See http://gbc-education.org/wp-content/uploads/2016/02/Tech_Report_ ONLINE.pdf

${ }^{51}$ See Atkins, D., Brown, J. \& Hammond, A. (2007). A review of the open educational resources (OER) movement: Achievements, challenges, and new opportunities (pp 1-84). A report to the William and Flora Hewlett Foundation. See endnote 25.

${ }^{52}$ We strongly recommend the CERI/OECD report referenced earlier. It is a tour de force of ideas, projects, and improvements that would enliven the OER movement. We have touched upon many of them independently but the CERI/OECD treatment is more extensive. See http://www.oecd-ilibrary. org/docserver/download/9615061e.pdf?expires=1451782268\&id=id\&accn ame=guest $\&$ checksum $=$ A8C62EF8A123FB6D46F068B779098A8E. 
